\title{
Feeding selectivity by copepods grazing on natural mixtures of phytoplankton determined by HPLC analysis of pigments
}

\author{
E. J. H. Head, L. R. Harris \\ Biological Oceanography Division, Department of Fisheries and Oceans, Bedford Institute of Oceanography, PO Box 1006, \\ Dartmouth, Nova Scotia, Canada B2Y 4A2
}

\begin{abstract}
During a period of $8 \mathrm{~d}$ in late September and early October 1992, 5 grazing experiments were carried out in an area off the coast of Morocco. Water was collected from the depth of the chlorophyll maximum and fed to copepods of either 500 to $1000 \mu \mathrm{m}$ or 200 to $500 \mu \mathrm{m}$ in size. Two chlorophylls and 2 carotenoids dominated the pigment composition of the particulate material: chlorophyll (chl) $a_{i}$ chl $c\left(c_{1}+c_{2}\right)$; fucoxanthin and 19-hexanoyloxyfucoxanthin. Initial concentrations of chl $a$ in experiments were between 0.4 and $2.2 \mu^{-1} ~^{-1}$ and those of chl c were between 0.04 and $0.54 \mu \mathrm{g} \mathrm{l}^{-1}$ Initial concentrations of fucoxanthin were between 0.1 and $1.1 \mathrm{\mu g} \mathrm{l}^{-1}$ and those of 19-hexanoyloxyfucoxanthin between 0.07 and $0.32 \mu \mathrm{g} \mathrm{I}^{-1}$. The ratio of fucoxanthin: 19-hexanoyloxyfucoxanthin varied between 0.3 and $15(\mathrm{w} / \mathrm{w})$. The fucoxanthin was probably associated with diatoms and the 19-hexanoyloxyfucoxanthin with prymnesiophytes. Some chl a-derived fluorescent breakdown products were found in faecal pellets collected after grazing, but neither fucoxanthin nor 19-hexanoyloxyfucoxanthin were present. Hence these carotenoids were destroyed following ingestion by copepods, so that decreases in their concentrations in the incubation medium could be used to measure grazing rates on the different types of phytoplankton independently. In this way it was shown that copepods 500 to $1000 \mu \mathrm{m}$ in size fed preferentially on diatoms, and that their overall feeding rate was depressed when fucoxanthin: 19-hexanoyloxyfucoxanthin ratios were relatively low. By contrast, copepods 200 to $500 \mu \mathrm{m}$ in size fed randomly or preferred the prymnesiophytes. When chl a concentrations were initially $<1 \mu g l^{-1}$, then for both size ranges of copepods, only a very small proportion $(<10 \%)$ of the ingested chl a was converted into a-type phaeopigments, the rest apparently being destroyed during digestion. In one case, however, when copepods 200 to $500 \mu \mathrm{m}$ were fed with water in which the initial chl a concentration was $>2 \mu \mathrm{gl}^{-1}$, about $30 \%$ of ingested chl a was recovered in a-type phaeopigments.
\end{abstract}

KEY WORDS: Algal pigment destruction · Feeding selectivity $\cdot$ Copepods

\section{INTRODUCTION}

Measurements of chlorophyll (chl) a and phaeopigment, made using a Turner fluorometer, have shown that when phytoplankton are ingested by copepods, some proportion (range 10 to $90 \%$ ) of the chl a that they contain is defecated in faecal pellets as phaeopigment, while the rest is degraded further into undetectable products (Head 1988, Lopez et al. 1988, Penry \& Frost 1991). These results have been criticised, however, because interference by other pigments may lead to inaccuracies in the calculated concentrations of the a-type chlorophylls and phaeopigments. More recently, analysis of pigment composition by high performance liquid chromatography (HPLC) has shown that Calanus spp. grazing on diatoms transformed between 10 and $80 \%$ of the chl $a$ they ingested into varying proportions of pyrophaeophytin a and pyrophaeophorbide $a$, and the rest into unidentifiable or undetectable products (Head \& Harris 1992). In these experiments ingested chl $c\left(c_{1}+c_{2}\right)$ was more extensively degraded than chl $a_{1}$ so that only small quantities of pyrolized demetallated product were ever found in faecal pellets. In addition, the copepods also metab- 
olized the carotenoids present in the algae, so that ingested fucoxanthin was completely absent from faecal pellets, and diadinoxanthin concentrations were very low. These latter findings contradict the results of previous studies which suggested that carotenoids might be more resistant to digestion than chlorophylls during passage through copepod guts (Kleppel et al. 1988, 1991, Nelson 1989).

Between September 28 and October 7, 1992, the Biological Oceanography Division of the Bedford Institute of Oceanography conducted a 'JGOFS' study in an area of upwelling off the coast of Morocco. The phytoplankon concentration and community structure within the sampling area were very variable (E. J. H. Head, W. G. Harrison, B. Irwin \& E. P. W. Horne unpubl.). The depth of the chlorophyll maximum varied between the surface and $30 \mathrm{~m}$ and the chl a concentration at that depth var-

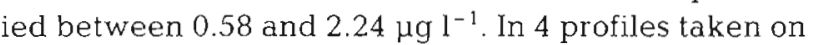
September 30 and October 2, 4 and 5, detalled pigment analysis by HPLC showed that concentrations of 19 hexanoyloxyfucoxanthin were always between 0.1 and $0.2 \mu \mathrm{g} \mathrm{I}^{-1}$ in the 0 to $30 \mathrm{~m}$ depth range, and that about $60 \%$ of the 19 -hexanoyioxyiucoxaninin was assuciated with cells of less than $1 \mu \mathrm{m}$ in size. Fucoxanthin concentrations in these 4 profiles were more variable in the top $30 \mathrm{~m}$, with a range of about 0.10 to $0.85 \mathrm{\mu g} \mathrm{l}^{-1}$. The highest concentrations of fucoxanthin were associated with near-surface chlorophyll maxima and with cells of which about $80 \%$ were larger than $1 \mu \mathrm{m}$ and about $60 \%$ smaller than $53 \mu \mathrm{m}$ in size. Carotenoids, and to a lesser extent chlorophylls, are distributed amongst the algae along taxonomic lines (Rowan 1989). Fucoxanthin is most often found in association with diatoms, while 19hexanoyloxyfucoxanthin is usually associated with prymnesiophytes. Thus, the phytoplankton community in this area consisted of mixtures of varying proportions of prymnesiophytes, which were small, and diatoms, which were larger.

As part of our 'JGOFS' program, we carried out grazing experiments in which copepods in the 500 to $1000 \mu \mathrm{m}$ and 200 to $500 \mu \mathrm{m}$ size ranges were fed with natural seawater. Pigment analysis by HPLC is routine in these studies so that there can be unequivocal estimates of the degree of chl a destruction which occurs during grazing, which can be used to convert estimates of in situ copepod defecation rates to in situ ingestion rates (SCOR 1990a). In this case, however, because the phytoplankton was comprised of mainly 2 types, which had different carotenoids associated with them, and because, as we will show below, the copepods destroyed all of the 19-hexanoyloxyfucoxanthin and fucoxanthin that they ingested, changes in the concentrations of these carotenoids in the water could be used to measure consumption rates for prymnesiophytes and diatoms independently.

\section{MATERIALS AND METHODS}

Sample collection. Copepods and water were collected for Expts 1 to 5 on September 30 and October 2, 4,5 and 7 . The copepods were collected using a $200 \mu \mathrm{m}$ mesh ring net of $0.75 \mathrm{~m}$ diameter, which was towed vertically between $120 \mathrm{~m}$ and the surface. Immediately following capture the copepods were screened through a $1 \mathrm{~mm}$ (Expts 1 to 3 ) or a $500 \mu \mathrm{m}$ mesh (Expts $4 \&$ 5) on to a $500 \mu \mathrm{m}$ (Expts 1 to 3) or $200 \mu \mathrm{m}$ (Expts 4 \& 5) mesh, immersed in a bucket of filtered $(0.2 \mu \mathrm{m})$ seawater (FSW). They were then rinsed by transferring the screen to a second bucket of FSW. Finally the copepods were washed off into an 81 carboy of FSW. The carboy was immersed in a covered tank, through which surface seawater was continuously running. Seawater to be used to feed the copepods was collected using a $30 \mathrm{l}$ Niskin bottle from near the depth of the chiorophyll maximum. It was kept in carboys in the covered tank until the experiments were set up. Copepods and water were collected between 19:30 and 20:15 h.

Experimental procedures. Experimental procedures were very similar to those used by Head \& Harris (1992). At about $22: 30 \mathrm{~h}$ the seawater to be fed to the copepods was screened using a $53 \mu \mathrm{m}$ mesh, to remove particulates similar in size to the faecal pellets which were to be collected after the experiments. The screened seawater was divided between three 81 plastic carboys. Samples of copepods, which had been incubated in FSW for about $3 \mathrm{~h}$, were concentrated on a $500 \mu \mathrm{m}$ (Expts 1 to 3) or $200 \mu \mathrm{m}$ (Expts 4 \& 5) mesh, and divided into 2 equal portions. The portions were added to 2 of the carboys of food, which were then inverted several times. The third carboy, containing no copepods, was the control. Immediately following the addition of the copepods to a carboy, a subsample (21) was drawn off and filtered through a $500 \mu \mathrm{m}$ (Expts 1 to 3) or $200 \mu \mathrm{m}$ (Expts 4 \& 5) mesh. The copepods so collected were rinsed and filtered on to Sharkskin filters, and placed in a freezer $\left(-20^{\circ} \mathrm{C}\right)$, for subsequent gut pigment analysis using a Turner fluorometer. Subsamples of the water, from which the copepods had been removed, were then filtered on to GF/C filters for the determination of pigment concentration using HPLC (500 ml). The controls were subsampled in the same way as the experimental carboys had been. All operations were carried out under conditions of subdued light. Filters were stored in liquid nitrogen until HPLC analysis in the laboratory 1 to 2 mo later.

The feeding incubations were carried out in the dark at $20^{\circ} \mathrm{C}$, which was within $2^{\circ} \mathrm{C}$ of the ambient surface water temperature. After $8 \mathrm{~h}$ (at about 07:00 h) the carboys were gently inverted several times and subsamples ( 2 l) were drawn off and treated as they had been 
at the begining of the experiment. The volumes remaining in the carboys which had contained copepods were then measured and the copepods were screened off using either a $500 \mu \mathrm{m}$ (Expts 1 to 3 ) or $200 \mu \mathrm{m}$ (Expts 4 \& 5) mesh and preserved ( $2 \%$ formalin) for enumeration and species identification. The water remaining from both of the experimental carboys was then combined. After concentration to about $2 \mathrm{l}$ by reverse filtration $(53 \mu \mathrm{m})$, the water was sieved through a $76 \mu \mathrm{m}$ (Expts 1 to 3 ) or $53 \mu \mathrm{m}$ (Expts 4 \& 5) mesh, to collect the faecal pellets which had been produced during grazing. The faecal pellets were rinsed briefly (FSW), resuspended in FSW $(500 \mathrm{ml})$, mixed thoroughly, but gently, and then subsampled by filtration on to GF/C filters for pigment analysis by HPLC (350 ml).

Sample analysis. Measurement of chlorophyll and phaeopigment concentrations in copepod guts were made using a Turner fluorometer, as has been described previously (Head 1992). Analysis of pigments was carried out using a Beckman HPLC system, as described by Head \& Horne (1993), using a method based on that of Gieskes \& Kraay (1989). All recognized phaeopigments are reported as their respective chlorophyll equivalent weights, and unknown fluorescent peaks, having retention times close to those of known phaeophorbides or phaeophytins, were quantified as if they were phaeophorbide a-like pigments.

\section{RESULTS}

Copepods from 4 genera constituted over $68 \%$ of the communities in the 500 to $1000 \mu \mathrm{m}$ size range (Expts 1 to 3): Temora, Calanus, Nannocalanus and Centropages (Table 1). Copepods included in the 'Other ' cat- egory in this size range were generally small calanoids, so that the average weight per copepod was lower in Expts $2 \& 3$, where the number of unidentified individuals was between 18 and $31 \%$, than in Expt 1 , where the number of unidentified copepods was 3 or $4 \%$ Unidentified calanoids made up over $77 \%$ of the copepods in the 200 to $500 \mu \mathrm{m}$ size range in Expts 4 $\& 5$.

The 4 most abundant pigments in all of the experiments before grazing were: chl a, fucoxanthin, 19-hexanoyloxyfucoxanthin and chl $c$ (Figs. 1 \& 2, Table 2). Together they always made up between 73 and $91 \%$ of the total pigment. The next most abundant pigments were diadinoxanthin, chl $b$ and zeaxanthin/lutein (not resolved in our system). If these had been included in the calculations then these 8 pigments would have made up between 85 and $97 \%$ of the total pigment. In Expts 1 to 3 copepods were fed with water in which the initial concentration of chl a was less than $0.75 \mathrm{\mu g} \mathrm{l}^{-1}$, and in which the fucoxanthin:19-hexanoyloxyfucoxanthin ratio $(w / w)$ was either about 1 (Expts $1 \& 2$ ) or 4 (Expt 3). In Expt 4 the initial concentration of chl $a$ in the water was over $2 \mu \mathrm{g} \mathrm{l}^{-1}$ and the ratio of fucoxanthin:19-hexanoyloxyfucoxanthin was over $15(\mathrm{w} / \mathrm{w})$. In Expt 5 the initial chl a concentration was about $0.8 \mu \mathrm{g}$ $\mathrm{I}^{-1}$ and the ratio of fucoxanthin:19-hexanoyloxyfucoxanthin was about $0.3(\mathrm{w} / \mathrm{w})$.

Faecal pellets from large and small copepods were not very abundant and were pale in colour and apparently contained only very low levels of pigments (Figs. 1 \& 2). Carotenoids could not be identified or quantified properly because of their low concentrations, but because the fluoresence detector is more sensitive than the UV-visible detector, the fluorescent pigments were more easily recognized. The low levels of chl $a, b$ and $c$ seen in pellet samples may have been

Table 1. Species composition of copepods from Expts 1 to 5

\begin{tabular}{|c|c|c|c|c|c|c|c|c|}
\hline \multirow[t]{2}{*}{ Expt } & & \multicolumn{5}{|c|}{ Species composition (\%) } & \multirow{2}{*}{$\begin{array}{l}\text { Total no. of } \\
\text { copepods } \\
\text { (ind. } 1^{-1} \text { ) }\end{array}$} & \multirow{2}{*}{ 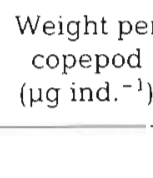 } \\
\hline & Temora & Calanus & Nannocalanus & Centropages $\mathrm{C}$ & Other copepods & Euphausiids & & \\
\hline $1 \mathrm{a}$ & 39.9 & 14.0 & 21.3 & 15.9 & 3.1 & 5.8 & 195 & 41.21 \\
\hline $1 b$ & 35.8 & 11.6 & 30.5 & 14.2 & 3.8 & 4.1 & 264 & 41.97 \\
\hline $2 a$ & 36.7 & 8.4 & 7.2 & 13.3 & 31.3 & 3.0 & 142 & 27.00 \\
\hline $2 b$ & 41.5 & 9.4 & 11.1 & 14.6 & 21.1 & 2.3 & 133 & 33.69 \\
\hline $3 a$ & 28.9 & 7.9 & 11.9 & 26.1 & 19.8 & 5.5 & 192 & 26.69 \\
\hline \multirow[t]{2}{*}{$3 b$} & 24.5 & 13.0 & 14.7 & 26.1 & 17.9 & 3.8 & 150 & 35.58 \\
\hline & \multicolumn{2}{|c|}{ Calanoids } & Cyclopoids & Other copepods & Nauplii & & & \\
\hline $4 \mathrm{a}$ & \multicolumn{2}{|c|}{80.9} & 15.2 & 0.6 & 3.3 & & 355 & 4.87 \\
\hline $4 \mathrm{~b}$ & \multicolumn{2}{|c|}{77.8} & 19.0 & 0.0 & 3.2 & & 402 & 4.11 \\
\hline $5 a$ & \multicolumn{2}{|c|}{80.0} & 19.0 & 0.2 & 0.8 & & 432 & 4.26 \\
\hline $5 b$ & \multicolumn{2}{|c|}{83.6} & 15.2 & 0.2 & 1.0 & & 411 & 4.00 \\
\hline
\end{tabular}



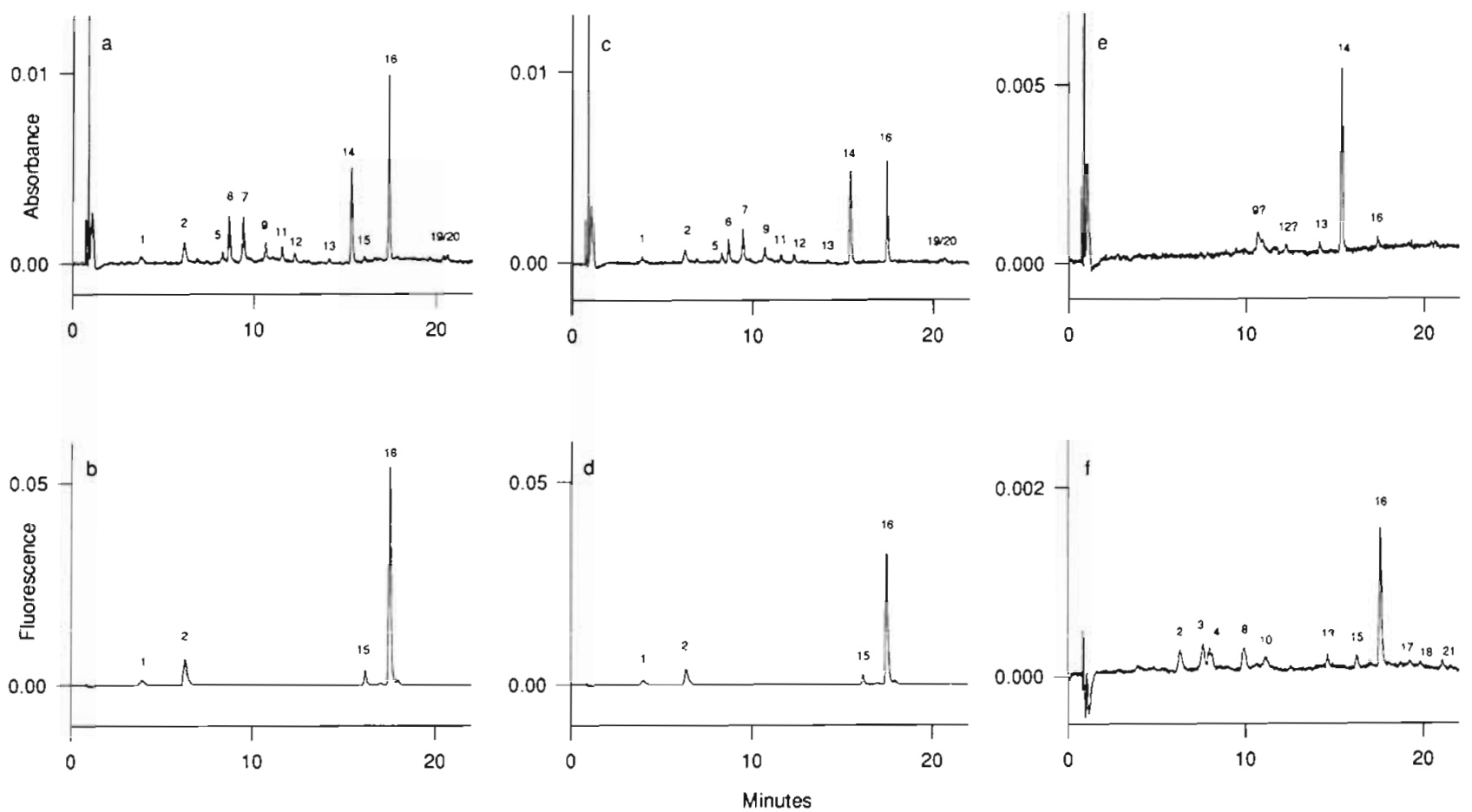

Fig. 1. Absorption $(a, c \& e)$ and fluorescence $(b, d \& f)$ chromatograms of seawater before (a \& b) and after (c \& d) grazing by copepods 500 to $1000 \mu \mathrm{m}$ in size and of faecal pellets (e \& f) collected after grazing in Expt 2. Peak identification: (1) chl $c_{3} ;(2) \mathrm{chl} c$ $\left(c_{1}+c_{2}\right)_{i}(3)$ unknown (a-type phaeopigment?); (4) unknown (a-type phaeopigment?); (5) 19-butanoyloxyfucoxanthin; (6) fucoxanthin; (7) 19-hexanoyloxyfucoxanthin; (8) pyrophaeophorbide $a_{i}$ (9) diadinoxanthin; (10) pyrophaeoporphyrin $c(?) ;(11)$ alloxanthin (?); (12) zeaxanthin/lutein; (13) unknown; (14) unknown contaminant; (15) chl $b_{i}(16)$ chl a (+ isomers); (17) unknown (phaeophytin a-like?); $(18)$ phaeophytin $a_{i}(19,20)$ carotenes $(21)$ pyrophaeophytin a. Note that Peak 14 , which had a retention time unlike that of any common algal pigment, was present in all samples (but not solvent blanks) and always gave the same peak height and area. For this reason we think that it was a contaminant on the GF/C filters, which had not been pre-baked and might therefore have contained traces of organic material

present because of contamination by a few intact algal cells, but these were not obvious when the faecal pellets samples on GF/C filters were examined under the microscope. Pyrophaeophorbide a, a product known to be produced by copepods from chl a (Head \& Harris 1992, Head \& Horne 1993), was present in pellets from both size classes of copepods. A fluorescent peak with a retention time appropriate for a pyrophaeoporphyrin c-like pigment (Head \& Harris 1992) was also seen in faecal pellets from the larger copepods (Fig. 1). Otherwise there were 2 unidentified fluorescent peaks in the phaeophorbide region of the chromatograms, which occurred in different proportions in the 2 types of pellet (Peaks 3 \& 4; Figs. 1 \& 2). Three phaeophytins were also present in trace quantities. Because faecal pellets contained undetectable quantities of carotenoids and insignificant concentrations of intact chl $a$ and $c$, changes in the concentrations of these 4 pigments in the incubation medium could be used as measures of grazing on each pigment.

In the control carboys the concentrations of all of the pigments changed by less than $16 \%$ during the incu- bation period, and usually by less than $10 \%$. In general the changes in control carboys were small compared with the decreases in the concentrations of pigments which occurred in experimental carboys during grazing (Table 2). Changes in controls were ignored in calculations of ingestion and apparent filtration rates (Table 3), which were made according to the equations of Frost (1972), as modified by Marin et al. (1986). The term 'apparent' filtration rate is used in Table 3 to indicate that it should be recognized that when copepods are grazing selectively the simple meaning of the term filtration rate does not really apply. Comparisons of the percent consumption of species or class specific pigments in the diet (i.e. fucoxanthin and 19-hexanoyloxyfucoxanthin) can be used to assess grazing selectivity, but since both chl $a$ and $c$ are present in both prymnesiophytes and diatoms, percent consumption on these pigments represents a combined value. Calculations of apparent filtration rates for the pigments can also be used to compare grazing activity on the different algae within an experiment, but in addition they can also be used to compare overall grazing activity 

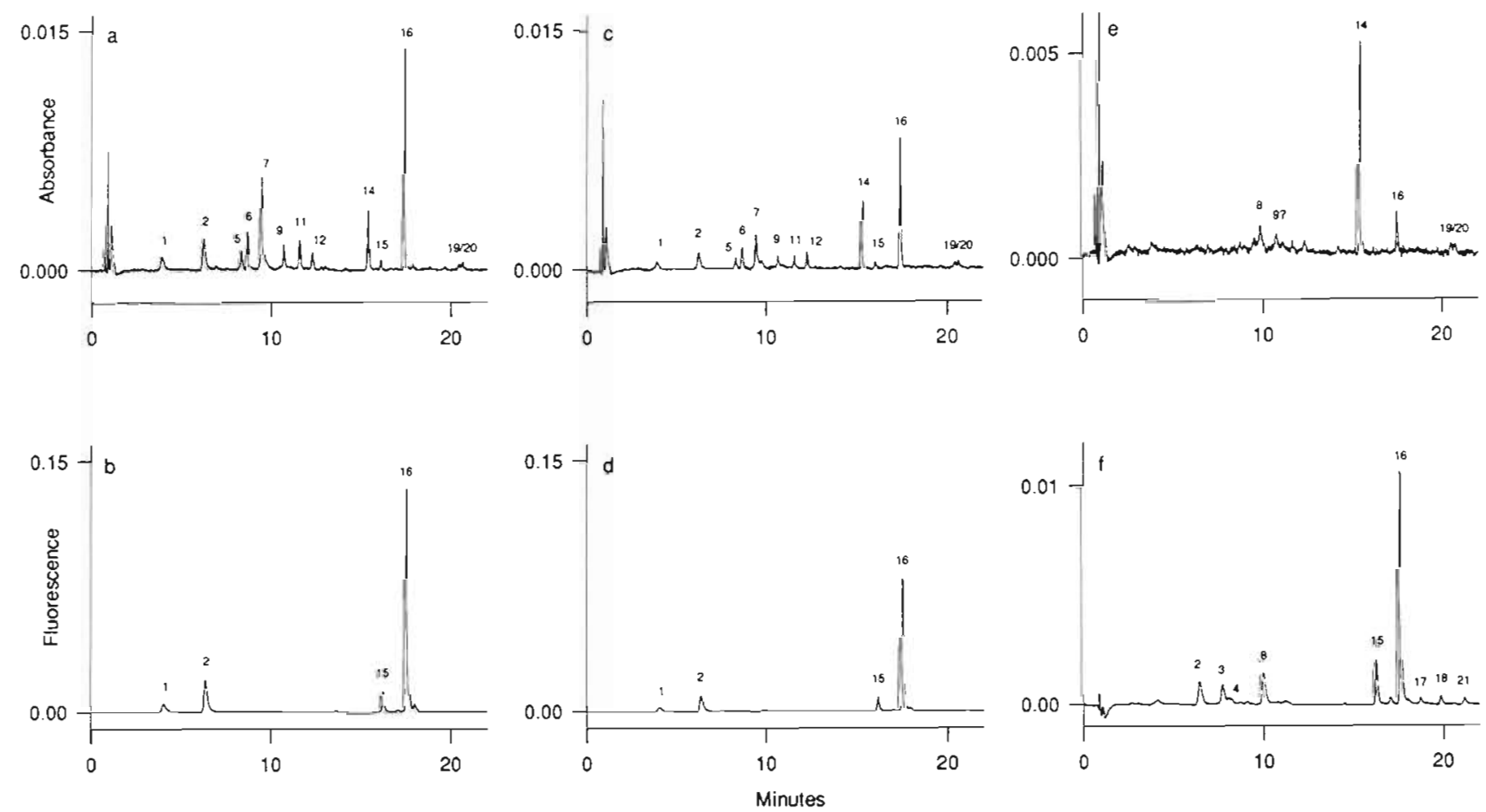

Fig. 2. Absorption ( $a, c \&$ e) and fluorescence (b, d \& f) chromatograms of seawater before (a \& b) and after (c \& d) grazing by copepods 200 to $500 \mu \mathrm{m}$ in size and of faecal pellets (e \& f) collected after grazing in Expt 5. Peak identifications as in Fig. 1

between experiments. In the first 3 experiments, the percentage of 19-hexanoyloxyfucoxanthin consumed by the large copepods was always much less than those of any of the other 3 pigments and percentages of $\mathrm{chl} a$ and consumed were intermediate (Table 3 ). The apparent filtration rate on 19-hexanoyloxyfucoxanthin was also lower in all 3 experiments, but in addition, all filtration rates were substantially higher in Expt 3, where the ratio of fucoxanthin:19-hexanoyloxyfucoxanthin was 4, as compared with Expts 1 \& 2, where it was about 1. In Expts $4 \& 5$ the percentage of 19hexanoyloxyfucoxanthin consumed by the small copepods was similar to (Expt 4), or higher than (Expt 5), those of all of the other pigments, and filtration rates showed no discernible differences between experiments, although there was a 50 -fold change in the fucoxanthin:19-hexanoyloxyfucoxanthin ratio.

Pigment concentrations in copepod guts were negligible in all experiments both at the begining and end of the incubation period. For calculations of the degree of chl a destruction during grazing presented in Table 3, the amount of chl a (plus isomers) consumed was compared with the increase in the sum of the amounts of phaeopigments before and after grazing in Peaks $3,4,8,17,18$ and 21 (Figs. $1 \& 2$ ), which were either known (Peaks 8, 18 \& 21), or assumed (Peaks 3, $4 \& 17$ ), to be a-type phaeopigments. In Expt 1 no phaeopigments were detectable before or after graz- ing, but because the detection limit for a-type phaeopigments in our system was approximately $10 \mathrm{ng} \mathrm{l}^{-1}$ (in the incubation medium), this value was used to estimate a minimum value for the degree of destruction. In Expts $2 \& 3$ the concentrations of the unknown phaeopigments (Peaks 3, 4 \& 17; Figs. 1 \& 2) were also undetectably low in the water after grazing. In Expt 2, the calculation of the degree of chl a destruction gave a value of $>100 \%$ because there were low levels of phaeophytin $a$ in the water before grazing which decreased in experimental bottles during grazing, which were not compensated for by increases in concentrations of other a-type phaeopigments. In Expts 4 \& 5 the unknown phaeopigments, which were assumed to be a-type phaeopigments, accounted for $10 \%$ and $23 \%$, respectively, of the total a-type phaeopigment. If the unknown phaeopigments had been excluded from the budget calculations then the degree of chl a destruction would have been $70 \%$ and $94 \%$ in Expts 4 \& 5, respectively.

\section{DISCUSSION}

Food concentration and previous feeding history both affect the degree of chl a destruction which occurs when copepods feed on algae in incubation experiments and also, perhaps, in situ (Penry \& Frost 
Table 2. Pigment composition ( 4 most abundant pigments and sum of these 4 pigments as \% of total pigment) of particulate material in seawater fed to copepods, before and after grazing. The initial values are the means ( \pm SD) for all 3 carboys

\begin{tabular}{|c|c|c|c|c|c|}
\hline Carboy & $\begin{array}{l}\text { Chl } c \\
\left(\operatorname{ng~I^{-1}}\right)\end{array}$ & $\begin{array}{c}\text { Fucoxanthin } \\
\left(\text { ng } !^{-1}\right)\end{array}$ & $\begin{array}{l}\text { 19-hexanoyloxy- } \\
\text { fucoxanthin } \\
\left.\text { (ng } ~^{-1}\right)\end{array}$ & $\begin{array}{l}\text { Chl a } \\
\left(\mathrm{ng} \mathrm{l}^{-1}\right)\end{array}$ & $\begin{array}{l}\% \text { of total } \\
\text { pigment }\end{array}$ \\
\hline \multicolumn{6}{|l|}{ Expt 1} \\
\hline Initial conc. & $\begin{array}{c}70.09 \\
( \pm 4.86)\end{array}$ & $\begin{array}{l}156.35 \\
( \pm 8.73)\end{array}$ & $\begin{array}{c}146.94 \\
( \pm 2.97)\end{array}$ & $\begin{array}{c}699.79 \\
( \pm 46.50)\end{array}$ & 80 \\
\hline \multicolumn{6}{|l|}{ Final conc. } \\
\hline Control & 70.56 & 154.99 & 134.14 & 677.31 & 80 \\
\hline $1 \mathrm{a}$ & 35.77 & 80.83 & 100.02 & 377.44 & 81 \\
\hline $1 \mathrm{~b}$ & 38.42 & 80.83 & 105.98 & 393.18 & 80 \\
\hline \multicolumn{6}{|l|}{ Expt 2} \\
\hline Initial conc. & $\begin{array}{c}44.01 \\
( \pm 1.40)\end{array}$ & $\begin{array}{c}115.32 \\
( \pm 4.28)\end{array}$ & $\begin{array}{c}100.24 \\
( \pm 5.47)\end{array}$ & $\begin{array}{c}436.59 \\
( \pm 26.73)\end{array}$ & 83 \\
\hline \multicolumn{6}{|l|}{ Final conc. } \\
\hline Control & 46.22 & 118.29 & 112.28 & 382.50 & 84 \\
\hline $2 \mathrm{a}$ & 26.64 & 61.92 & 81.81 & 228.76 & 80 \\
\hline $2 b$ & 25.55 & 52.65 & 85.12 & 221.50 & 81 \\
\hline \multicolumn{6}{|l|}{ Expt 3} \\
\hline Initial conc. & $\begin{array}{c}88.84 \\
( \pm 0.81)\end{array}$ & $\begin{array}{c}280.32 \\
( \pm 5.97)\end{array}$ & $\begin{array}{c}71.10 \\
( \pm 1.70)\end{array}$ & $\begin{array}{c}730.61 \\
( \pm 23.60)\end{array}$ & 91 \\
\hline \multicolumn{6}{|l|}{ Final conc. } \\
\hline Control & 94.22 & 302.47 & 65.77 & 742.78 & 93 \\
\hline $3 a$ & 21.74 & 67.11 & 35.77 & 218.32 & 85 \\
\hline $3 b$ & 22.64 & 67.49 & 39.41 & $2 \mathrm{i} 4 . \mathrm{ii}$ & 84 \\
\hline \multicolumn{6}{|l|}{ Expt 4} \\
\hline Initial conc. & $\begin{array}{c}536.71 \\
( \pm 28.59)\end{array}$ & $\begin{array}{c}1100.78 \\
( \pm 52.44)\end{array}$ & $\begin{array}{c}71.65 \\
( \pm 14.46)\end{array}$ & $\begin{array}{c}2194.21 \\
( \pm 164.45)\end{array}$ & 86 \\
\hline \multicolumn{6}{|l|}{ Final conc. } \\
\hline Control & 539.91 & 1166.54 & 72.86 & 2355.38 & 87 \\
\hline $4 a$ & 382.64 & 841.35 & 45.71 & 1645.20 & 80 \\
\hline $4 b$ & 313.06 & 683.38 & 45.71 & 1448.76 & 79 \\
\hline \multicolumn{6}{|l|}{ Expt 5} \\
\hline Initial conc. & $\begin{array}{c}140.97 \\
( \pm 6.01)\end{array}$ & $\begin{array}{c}116.80 \\
( \pm 7.71)\end{array}$ & $\begin{array}{c}318.95 \\
( \pm 33.73)\end{array}$ & $\begin{array}{c}802.30 \\
( \pm 113.44)\end{array}$ & 73 \\
\hline \multicolumn{6}{|l|}{ Final conc. } \\
\hline Control & 139.13 & 134.60 & 279.20 & 826.68 & 73 \\
\hline $5 a$ & 66.56 & 66.00 & 110.95 & 396.54 & 66 \\
\hline $5 b$ & 66.47 & 72.31 & 124.20 & 408.60 & 65 \\
\hline
\end{tabular}

1991, Head 1992, Head \& Harris 1992). Destruction appears to be relatively extensive when copepods are fed at low food concentrations, and when they have been feeding for some time before experimentation. By contrast, destruction seems to be less extensive when copepods are fed at high concentrations, or have been starved for an extended period ( $24 \mathrm{~h}$ ) before feeding. In our present study the copepods were starved for only $3 \mathrm{~h}$ before feeding and the degree of destruction of chl a during digestion was very high when food concentrations were $<1 \mu \mathrm{g} \mathrm{l}^{-1}$, and lower when the food concentration was $>2 \mu g 1^{-1}$ (Tables $2 \& 3$ ). These results are consistent with previous findings, although it is possible that pigment destruction was actually less extensive in situ than it was in these experiments, because elsewhere it has been suggested that copepods which had been starved for $12 \mathrm{~h}$ prior to feeding, destroyed ingested chl a to the same extent as they did in situ (Head 1992). The faecal pellets that we collected contained undetectably low levels of chl $c$ and fucoxanthin, confirming our previous suggestion that these pigments are more extensively degraded than chl a during digestion by copepods (Head \& Harris 1992). In addition, however, in this case we have shown that ingested 19-hexanoyloxyfucoxanthin was also completely destroyed during grazing. Fucoxanthin and 19hexanoyloxyfucoxanthin share similar chemical structures, so that it is not surprising that both should be degraded to the same extent during digestion. The presence of intact carotenoids in copepod guts or faecal pellets in other studies has suggested that pigment analysis might provide a method of looking at in situ dietary selection (Kleppel et al. 1988, 1991), but our results do not support this idea. Even if pigment (including carotenoid) degradation was not as complete for copepods grazing in situ as it was in these 
Table 3. Pigment ingestion, 'apparent' filtration rate and degree of chl a destruction in Expts 1 to 5 (average of a and b incubations) for copepods grazing on mixtures of algae. 19-Hex.: 19-hexanoyloxyfucoxanthin

\begin{tabular}{|c|c|c|c|c|}
\hline Pigment & $\begin{array}{l}\text { Pigment ingested during } \\
\text { incubation ( } \% \text { initial conc.) }\end{array}$ & $\begin{array}{l}\text { lngestion rate } \\
\text { (ng ind. }{ }^{-1} \mathrm{~h}^{-1} \text { ) }\end{array}$ & $\begin{array}{l}\text { Apparent filtration rate } \\
\left(\mathrm{ml} \text { ind. }{ }^{-1} \mathrm{~h}^{-1}\right)\end{array}$ & $\begin{array}{c}\text { Degree of destruction } \\
\qquad(\%)\end{array}$ \\
\hline \multicolumn{5}{|l|}{ Expt 1} \\
\hline $\mathrm{Chl} \mathrm{C}$ & 47 & 0.030 & 0.43 & \\
\hline Fucoxanthin & 48 & 0.067 & 0.43 & \\
\hline 19-Hex. & 30 & 0.033 & 0.23 & \\
\hline Chl a & 45 & 0.278 & 0.40 & $>97$ \\
\hline \multicolumn{5}{|l|}{ Expt 2} \\
\hline $\mathrm{Chl} c$ & 41 & 0.020 & 0.44 & \\
\hline Fucoxanthin & 50 & 0.073 & 0.63 & \\
\hline 19-Hex. & 17 & 0.019 & 0.19 & \\
\hline Chl a & 36 & 0.165 & 0.38 & 104 \\
\hline \multicolumn{5}{|l|}{ Expt 3} \\
\hline $\mathrm{Chl} \mathrm{C}$ & 75 & 0.118 & 1.32 & \\
\hline Fucoxanthin & 76 & 0.376 & 1.34 & \\
\hline 19-Неx. & 48 & 0.042 & 0.59 & \\
\hline Chl a & 71 & 0.867 & 1.19 & 97 \\
\hline \multicolumn{5}{|l|}{ Expt 4} \\
\hline Chl C & 35 & 0.083 & 0.16 & \\
\hline Fucoxanthin & 31 & 0.139 & 0.13 & \\
\hline 19-Hex. & 36 & 0.015 & 0.20 & \\
\hline Chl a & 29 & 0.294 & 0.14 & 67 \\
\hline \multicolumn{5}{|l|}{ Expt 5} \\
\hline $\mathrm{Chl} C$ & 53 & 0.027 & 0.19 & \\
\hline Fucoxanthin & 41 & 0.014 & 0.12 & \\
\hline 19-Hex. & 63 & 0.073 & 0.23 & \\
\hline Chla & 50 & 0.122 & 0.15 & 92 \\
\hline
\end{tabular}

experiments, it was probably not negligible. On the other hand, however, if complete degradation of carotenoids in incubation experiments is common, then we suggest that HPLC pigment analysis techniques may provide a useful way of studying dietary selection in vitro.

Feeding selectivity has often been observed for copepods grazing on mixtures of algae or on natural particulate material. When fed mixtures of cultures and non-living particles (e.g. polystyrene beads or heat-killed algae), copepods often prefer larger particles (Frost 1972, Donaghay \& Small 1979, DeMott 1989), although they may reject large non-living ones (Donaghay \& Small 1979). They can also discriminate between algae of the same size on the basis of protein or nitrogen content (Libourel Houde \& Roman 1987. Cowles et al. 1988), toxicity (Huntley et al. 1986) and digestibility (DeMott 1989). When copepods feed on natural mixtures of particles they sometimes prefer larger ones (Allan et al. 1977, O'Conners et al. 1980, Ryther \& Sanders 1980), but often they choose those which are most abundant (Allan et al. 1977. Poulet 1980). They may also avoid distasteful (Hansen \& van Boekel 1991, Bautista et al. 1992) or toxic algal species (Huntley 1982). Finally there is some evidence that larger copepods prefer larger food items, while smaller copepods or microzooplankton choose smaller ones (Nival \& Nival 1976, Harris 1982, Strom \& Welschmeyer 1991), or feed non-selectively (Allan et al. 1977).

In these experiments the large-sized copepods (i.e. those between 500 and $1000 \mu \mathrm{m}$ ) ate a greater percentage of the diatoms than of the prymnesiophytes (Expts 1 to 3 ; Table 3), and in profiles of the water column, in which Nuclepore and GF/F filters were used to size-fractionate and collect the particulate material, the diatoms were larger than the prymnesiophytes (Head et al. unpubl.). By comparing the percent consumption of each pigment, however, we cannot deduce whether the copepods preferred diatoms over prymnesiophytes because they were bigger, or because of some other factor ('taste'). If, however, we consider filtration rate as an index of feeding activity, then in the 2 cases where the ratio of fucoxanthin:19-hexanoyloxyfucoxanthin was close to 1 (Expts 1 \& 2) the filtration rates were quite similar for the same pigment in each experiment. In contrast, however, in Expt 3 , where the fucoxanthin:19-hexanoyloxyfucoxanthin ratio was 4 , the filtration rates for all 4 pigments were higher. Now the lowest filtration rate for fucoxanthin was in Expt 1, whereas the lowest concentration of fucoxanthin was in Expt 2 (Tables 2 \& 3). Also the filtration rates for 19-hexanoyloxyfucoxanthin were 
lower in Expts 1 \& 2 than in Expt 3, although it was the latter which had the lowest concentration of 19-hexanoyloxyfucoxanthin. Thus, for either type of food, it does not seem that we were seeing a threshold feeding concentration, below which the copepods did not feed on that type of food. Instead, from these results it seems that the presence of a large proportion of perhaps 'distasteful' prymnesiophytes may have depressed overall feeding activity by the copepods in Expts 1 \& 2 . Such an effect has been seen elsewhere for Calanus pacificus grazing on pure and mixed cultures of acceptable or unacceptable dinoflagellates which were of similar size (Huntley et al. 1986). In these experiments we do not know which species of prymnesiophyte was (or were) present, but elsewhere the large colonial gelatinous prymnesiophyte Phaeocystis spp. was apparently avoided by copepods (Hansen \& van Boekel 1991, Bautista et al. 1992). In areas near to our sampling area the coccolithophorid prymnesiophyte Emiliana huxleyii was abundant in May and June 1990 (van Bleijswijk et al. 1991). Coccoliths from E. huxleyii and other species have been found in copepod faecal pellets (Bathmann et al. 1987, Voss 1991), suggesting that they are consumed, but individual coccoliths in these instances were over $1 \mu \mathrm{m}$ in diameter and intact cells 4 to 5 times larger, whereas here much of the prymnesiophyte pigment 19-hexanoyloxyfucoxanthin was apparently associated with particles $<1 \mu \mathrm{m}$ in size (Head et al. unpubl.), It is unfortunate that taxonomic analysis of phytoplankton was not part of our sampling program, but our experiments have still demonstrated feeding selectivity by copepods in the 500 to $1000 \mu \mathrm{m}$, which may have influenced the overall phytoplankton community structure in this area (E. J. H. Head \& L. R. Harris unpubl.).

The copepods in the 200 to $500 \mu \mathrm{m}$ size range consumed a slightly higher proportion of prymnesiophytes than of diatoms in Expts 4 \& 5, but despite a 50-fold difference in the ratio of fucoxanthin:19-hexanoyloxyfucoxanthin between the 2 experiments, there were no differences in filtration rates for any of the pigments (Tables $2 \& 3$ ). Thus it appears that the copepods in this size range were not feeding very selectively, although they may have favoured the apparently smaller prymnesiophytes, especially in Expt 5 where they were most abundant.

Pigment analysis by HPLC has been used to study selective grazing by microzooplankton (Burkill et al. 1987. Strom \& Welschmeyer 1991), which destroy ingested carotenoids, but this is the first case in which the technique has been used for larger crustacean zooplankton. The advantages of using HPLC analysis for examining grazing selectivity are, firstly, that it is much less time-consuming than counting cells under a microscope and, secondly, that it allows one to exam- ine grazing on different types of cell, which might not be distinguished by electronic particle counting, which differentiates particles solely on the basis of size. If HPLC pigment analysis were to be used on particulate material which had been appropriately size-fractionated before and after grazing, then both cell-size and cell-type grazing preferences could be distinguished. The method depends on knowledge of the pigment composition of the faecal pellets, to ensure that any particular pigment is, in fact, destroyed during grazing. This is can be accomplished within the experiments themselves, as shown here, and is a worthy aim in itself because at present our knowledge of the pathways of pigment degradation by copepods is still rather limited, and following pigment markers might provide a useful way to evaluate the role of copepods in pigment and carbon flux in the ocean (SCOR 1990b. Head \& Horne 1993).

\section{LITERATURE CITED}

Allan, J. D., Richman, S., Heinle, D. R., Huff, R. (1977). Grazing in juvenile stages of some estuarine calanoid copepods. Mar. Biol. 43: 317-331

Bathmann, U. V., Noji, T. T., Voss, M., Peinert, R. (1987). Copepod fecal pellets: abundance, sedimentation and content at a permanent station in the Norwegian Sea in May/June 1986. Mar. Ecol. Prog. Ser. 38: 45-51

Bautista, B., Harris, R. P, Tranter, P. R. G., Harbour, D. (1992). In situ copepod feeding and grazing rates during a spring bloom dominated by Phaeocystis sp. in the English Channel. J. Plankton Res. 14: 691-703

Burkill, P. H., Mantoura, R. F. C. Llewellyn, C. A., Owens, N. J. P. (1987). Microzooplankton grazing and selectivity of phytoplankton in coastal waters. Mar. Biol. 93: 581-590

Cowles, T. J., Olson, R. J., Chisholm, S. W. (1988) Food selection by copepods: discrimination on the basis of food quality. Mar. Biol. 100: 41-49

DeMott, W. R. (1989). Optimal foraging theory as a predictor of chemically mediated food selection by suspension-feeding copepods. Limnol. Oceanogr. 34: 140-154

Donaghay, P. L., Small, L. F. (1979). Food selection capabilities of the estuanne copepod Acartia clausi. Mar. Biol. 52: $137-146$

Frost, B. W. (1972). Effects of size and concentration of food particles on the feeding behavior of the marine planktonic copepod Calanus pacificus. Limnol. Oceanogr. 17: $805-815$

Geiskes, W. W. C., Kraay, G. W. (1989). Estimating the carbon-specific growth rate of the major algal species groups in eastern Indonesian waters by ${ }^{14} \mathrm{C}$ labeling of taxonspecific carotenoids. Deep Sea Res. 36: 1127-1139

Hansen, F. C., van Boekel, W. H. M. (1991). Grazing pressure of the calanoid copepod Temora longicornis on a Phaeocystis dominated spring bloom in a Dutch tidal inlet. Mar. Ecol. Prog. Ser. 78: 123-129

Harris, R. P. (1982). Comparison of the feeding behaviour of Calanus and Pseudocalanus in two experimentally manipulated enclosed ecosystems. J. mar. biol. Ass. U.K. 62: 71-91

Head, E. J. H. (1988). Copepod feeding behaviour and the measurement of grazing rates in vivo and in vitro. In: 
Boxshall, G. A., Schminke, H. K. (eds.) Biology of copepods. Hydrobiologia 167/168: 31-41

Head, E. J. H. (1992). Gut pigment accumulation and destruction by arctic copepods in vitro and in situ. Mar. Biol. 112: 583-592

Head, E. J. H., Harris, L. R. (1992). Chlorophyll and carotenoid transformation and destruction by Calanus spp. grazing on diatoms. Mar. Ecol. Prog. Ser. 86: 229-238

Head, E. J. H., Horne, E. P. W. (1993). Pigment transformation and vertical flux in an area of convergence in the North Atlantic. Deep Sea Res. II. 40: 329-346

Huntley, M. E. (1982). Yellow water in La Jolla Bay, California, July 1980. II. Suppression of zooplankton grazing. J. exp. mar. Biol. Ecol. 71: 23-31

Huntley, M. E., Sykes, P., Rohan, S., Marin, V. (1986). Chemically-mediated rejection of dinoflagellate prey by the copepods Calanus pacificus and Paracalanus parvus: mechanism, occurrence and significance. Mar. Ecol. Prog. Ser. 28: 105-120

Kleppel. G. S., Frazel, D., Pieper, R. E., Holliday, D. V. (1988). Natural diets of zooplankton off southern California. Mar. Ecol. Prog. Ser. 49: 231-241

Kleppel, G. S., Holliday, D. V., Pieper, R. E. (1991). Trophic interactions between copepods and microplankton: a question about the role of diatoms. Limnol. Oceanogr. 36: $172-178$

Libourel Houde, S. E., Roman, M. R. (1987). Effects of food quality on the functional ingestion response of the copepod Acartia tonsa. Mar. Ecol. Prog. Ser. 40: 69-77

Lopez, M. D. G., Huntley, M. E., Sykes, P. F. (1988). Pigment destruction by Calanus pacificus: impact on the estimation of water column fluxes. J. Plankton Res. 4: 715-734

Marin, V., Huntley, M. E., Frost, B. (1986). Measuring feeding rates of pelagic herbivores: analysis of experimental design and methods. Mar. Biol. 93: 49-58

Nelson, J. R. (1989). Phytoplankton pigments in macrozooplankton feces: variability in carotenoid alterations. Mar. Ecol. Prog. Ser. 52: 129-314

Nival, P., Nival, S. (1976). Particle retention efficiencies of an

This article was submitted to the editor herbivorous copepod Acartia clausi (adult and copepodite stages): effects on grazing. Limnol. Oceanogr. 21: 24-38

O'Conners, H. B. Jr, Biggs, D. C., Ninivaggi, D. V. (1980). Particle-size-dependent maximum grazing rates for Temora longicornis fed natural particle assemblages. Mar. Biol. 56: $65-70$

Penry, D. L., Frost, B. W. (1991). Chlorophyll a degradation by Calanus pacificus: dependence on ingestion rate and digestive acclimation to food resources. Limnol. Oceanogr. 36: $147-159$

Poulet, S. A. (1980). Comparison between five co-existing species of marine copepods feeding on naturally occurring particulate matter. Limnol. Oceanogr. 25: 1126-1143

Rowan, K. S. (1989). Photosynthetic pigments of algae. Cambridge Univ. Press, Cambridge, p. 65-164

Ryther, J. H., Sanders, J. G. (1980). Experimental evidence of zooplankton control of the species composition and size distribution of marine phytoplankton. Mar. Ecol. Prog. Ser. 3: $279-283$

SCOR (1990a). Joint Global Ocean Flux Study: Core Measurement Protocols. Joint Global Ocean Flux Study, Report No. 6. Scientific Committee on Oceanic Research, Dalhousie University, Halifax

SCOR (1990b). Joint Global Ocean Flux Study: Science Plan. Joint Global Ocean Flux Study, Report No. 5. Scientific Committee on Oceanic Research, Dalhousie University, Halifax

Strom, S. L., Welschmeyer, N. A. (1991). Pigment-specific rates of phytoplankton growth and microzooplankton grazing in the open subarctic Pacific Ocean. Limnol. Oceanogr. 36: 50-63

Van Bleijswijk, J., van der Wal, P., Kempers, R., Velhuis, M. (1991). Distribution of two types of Emiliana huxleyii (Prymnesiophyceae) in the northeast Atlantic region as determined by immunofluorescence and coccolith morphology. J. Phycol. 27: 566-570

Voss, M. (1991). Content of copeod faecal pellets in relation to food supply in Kiel Bight and its effect on sedimentation rate. Mar. Ecol. Prog. Ser. 75: 217-225

Manuscript first received: January 13, 1994

Revised version accepted: April 26, 1994 